J. Asiat. Soc. Bangladesh, Sci. 44(2): 159-171, December 2018

\title{
CHARACTERIZATION OF POND WATER CHEMISTRY AND ITS POTABILITY STATUS AT SOUTH-WEST COASTAL REGION OF BANGLADESH
}

\author{
S. K. SAHA ${ }^{* 1}$, AMINUR RAHMAN ${ }^{2}$ AND KRISHNA RANI BARAI ${ }^{3}$ \\ ${ }^{1}$ Department of Geology, University of Dhaka, Dhaka-1000, Bangladesh \\ ${ }^{2}$ Bangladesh Water Development Board, Dhaka, Bangladesh \\ ${ }^{3}$ University of Ghent, Belgium
}

\begin{abstract}
Dacope Upazilla under Khulna district is one of the most affected safe water scarcity regions like any other part of southwest coastal region of Bangladesh. The demands for drinking and cooking water in the area are mostly met from rainwater harvesting and pond water. Pond water from different stations of Dacope Upazilla was analyzed for assessing the water chemistry, source rock evaluation and its potability status. Thirty one samples were collected by purposive sampling and analyzed following standard methods. The analysis reveals that the cations and anions of the ground water showed the order of abundance as $\mathrm{Na}^{+}>\mathrm{Mg}^{++}>\mathrm{Ca}^{++}>\mathrm{K}^{+}$and $\mathrm{Cl}^{-}>\mathrm{SO}_{4}^{--}>\mathrm{HCO}_{3}^{-}$, respectively. Source rock deduction suggests that the water is mostly carbonate weathering of sea water or brine intrusion. Piper diagram suggests that the water is in saline condition. Ionic ratios also justify the aforesaid relations. The chemical constituent of water is $\left(\mathrm{Na}^{+}+\mathrm{K}^{+}\right)$and $\left(\mathrm{Cl}^{-}\right.$ $\left.+\mathrm{HCO}_{3}{ }^{-}\right)$type influenced by sea water, however, ponds are in transition zone influenced by tide. With reference to Bangladesh and WHO standards the research states that most pond water do not satisfy the potable quality, therefore management options need to be formulated for further exploitation.
\end{abstract}

Key words: Pond water, Chemistry, Coastal region, Potability

\section{Introduction}

The southwest coastal region of Bangladesh is characterized by a highly productive mangrove ecosystem; intricate web of life, unique type of biodiversity and world's largest sediment load estimated to be annually about 1.5 to 2.4 billion tons per year.

The area is gently slopping towards the regional slope to the south from the north. Morphological features as slope, elevation, drainage pattern, flooding condition in the area by the fluvial and tidal rivers, vegetation, settlement density and subsurface sediments encountered in the auger holes are jointly considered to classify the area into various geomorphic units. Tidal flats originated from marsh or boggy environment, flood basin, undifferentiated depression, point bars of the present and past fluvial cycle, sand bar, ox-bow lake, abandoned channel have occupied most of the mapped area and are

\footnotetext{
*Author for correspondence: Email: sks@du.ac.bd
} 
forming the low lying coastal region (Rashid 1991, Umitsu 1993). On the other hand, natural levee and flood plain deposits formed the elevated region mostly in the northern and some of the middle parts of the area. Elevation of the area ranges from 0.5 to $5.79 \mathrm{~m}$ above mean sea level. Highest elevation of the area is $5.79 \mathrm{~m}$ above mean sea level.

The southwest coastal region of Bangladesh suffers from an acute crisis of safe water. About 170,000 people of Dacope Upazilla under Khulna district in Bangladesh are suffering from lack of safe water (BBS 1996). The sources of drinking and cooking water are mostly met from rain water harvesting and ponds. There is limited number of tube wells and ponds. Most of the shallow tube wells are contaminated with saline water intrusion. Though the people depend on pond water round the year, the certainty of safe water is assured only during the 5 - 7 months of the monsoon. According to government sources $46 \%$ of the people of Dacope Upazilla have access to safe water, although 27$30 \%$ of the people have access to it (Saha et al. 2006).

The south west region of Bangladesh is vulnerable to frequent natural disasters and calamities due to its geo-hydro-physical settings. The area is ecologically sensitive and amongst the most productive ones in the country. Moreover, a massive destruction of the physical nature of the area has been done by the unplanned mammoth scale shrimp aquaculture and other associated activities which contaminated the safe water system with salinity. Pond water chemical characterization can find out the status of the problem that can carry proper solution of this problem.

\section{Materials and Methods}

Dacope Upazila is situated in Khulna district at the southwest coastal region of Bangladesh having total area of 991.85 square km, out of which 799.01 sq.km comprises forest area. The area located to the south of Khulna city between $22^{\circ} 24^{\prime} \mathrm{N}$ and $22^{\circ} 40^{\prime} \mathrm{N}$ latitude and between $89^{\circ} 24^{\prime}$ and $89^{\circ} 35^{\prime} \mathrm{E}$ longitudes.

Water samples from 31 ponds were collected from 9 Union and Chalna municipality area following the standard sampling procedure. The nine Unions were decoded as Dacope (D), Sutarkhali (S), Kamarkhola (K), Tildanga (T), Bajua (Bz), Kailashgonj (K), Laudobe (L), Pankhali (P), Banishanta (B) and Chalna Municipality (Ch).

The physico-chemical properties of water sample of the study area were conducted in the laboratory of the Department of Geology, University of Dhaka. The analysis of water temperature, $\mathrm{pH}$, salinity, electrical conductivity (EC) and total dissolved solid (TDS) was done in the field by the field kit test equipments. The values of other parameters of water sample such as sodium, potassium, calcium, silicate, sulfate, ortho phosphate were 
estimated by flame Photometer and Spectrophotometer, using standard methods (APHA 1992).

\section{Results and Discussion}

Status of surface water chemistry in Dacope Upazilla: The study deals with major components such as $\mathrm{Na}^{+}, \mathrm{K}^{+}, \mathrm{Ca}^{2+}, \mathrm{Mg}^{2+}, \mathrm{Cl}^{-}, \mathrm{HCO}_{3}{ }^{-}, \mathrm{SO}_{4}{ }^{2-}, \mathrm{PO}_{4}{ }^{3-}$ and $\mathrm{NO}_{3}{ }^{-}$of surface water. As the shallow and deep aquifers in the area are contaminated with saline water intrusion most of the people are habituated with consuming pond water. In some places pond water is treated through pond sand filter (PSF) which hardly can separate floating materials.

In the study area, most of the water $\mathrm{pH}$ ranged from 6.40 (Bz2) to 7.75 (D1) (Table 1), which show a very gentle $\mathrm{pH}$ range that satisfies the $\mathrm{pH}$ value of Bangladesh and WHO standard; pond water $\mathrm{pH}$ is suitable for domestic and irrigation purpose.

EC varied from $1.50(\mathrm{P} 1)$ to $14.25(\mathrm{Kl} 3) \mathrm{mS} / \mathrm{cm}$ in pond water. About $80 \%$ sample of the pond water is within $5 \mathrm{mS} / \mathrm{cm}$. It is also evident that TDS is not strongly correlated with $\mathrm{EC}$, where the correlation value is 0.015 . EC is negatively correlated with $\mathrm{Na}^{+}(-0.173)$, $\mathrm{K}^{+}(-0.118), \mathrm{Cl}^{-}(-0.147), \mathrm{Mg}^{2+}(-0.119)$ and poorly correlated with salinity $(0.044)$ (Table 2).

TDS varied from $5510 \mathrm{ppm}$ (P2) to $204 \mathrm{ppm}$ (B1) in pond water, where Bangladesh and WHO standard is $1000 \mathrm{ppm}$. Here $21.9 \%$ of the samples of pond water contained TDS above the standard. This may be due to the presence of $\mathrm{Ca}^{++}, \mathrm{Mg}^{++}$and $\mathrm{HCO}_{3}{ }^{-}$or $\mathrm{SiO}_{2}$ which may be due to intrusion of fertilizer/salt water from surrounding fishing ghers. In general, water with a total solid content of less than $500 \mathrm{mg} / \mathrm{l}$ is most desirable for such purposes. Water with higher solid contents often has a laxative and sometimes the reverse effect upon people.

In Dacope Upazilla surface water salinity varied from 0.05 (K2, Ch3) to 4 ppt (Bz2). Sample Bz2 shows salinity of 4000 ppm for its storage teqnique in earthen pot (Mutki).

The average concentration of sodium varies from 50 (D1) to 934 (S2) ppm in pond water and most of the pond water within $200 \mathrm{ppm}$. The highest value of sodium found at a pond of Sutarkhali union (S2) and lowest in ponds situated in Dacope Union (D1). The influencing factors of sodium may be due to the natural agencies such as storms, high tide and intrusion of seawater in coastal aquifer. In general sodium is a dominant cation in most mineralized groundwater. In humid environments, sodium flushed from the soil and unsaturated zones, whereas in more arid environments, the concentration of sodium in 
groundwater may be due to saltwater intrusion and humid environments (Sivasankaran and Ramesh 2005).

Potassium varied from 3.5 (Bz1) to 70 (S2) ppm in pond water in the study area. Most of them are within 10 and $30 \mathrm{ppm}$. Sixty four per cent of those samples contain potassium concentration above the standard value (12 ppm). The highest value found in a pond in Sutarkhali union (S2). Potassium exhibits positive correlation with $\mathrm{SO}_{4}{ }^{2-}(0.174), \mathrm{Mg}^{++}$ (0.451), $\mathrm{Na}^{+}(0.325), \mathrm{PO}_{4}^{3-}(0.021)$ and $\mathrm{Cl}^{-}(0.264)$. Potassium exhibits positive correlation with $\mathrm{Ca}^{++}, \mathrm{Mg}^{++}, \mathrm{HCO}_{3}{ }^{-}$and $\mathrm{Cl}^{-}$(Table 2). Because of its lower geochemical mobility in freshwater, potassium is seldom found in greater or almost equal concentration of sodium $\left(\mathrm{Na}^{+}\right)$. In spite of the greater resistance of K-feldspars and $\mathrm{K}$ silicates to the weathering, $\mathrm{K}^{+}$ions are released by weathering. However, after prolonged migration they tend to become fixed again through sorption on clay minerals and formation of secondary minerals (Matthess 1982).

In Dacope Upazilla calcium varied from $22 \mathrm{ppm}$ (Ch3) to 120 (L3) ppm in pond water. Almost all the samples (86\%) in the study area showed high concentration $(>10 \mathrm{mg} / \mathrm{l})$ of calcium, that means those concentrations fall out of range of natural freshwater. This high concentration may be due to primarily the presence of $\mathrm{CO}_{2}$ which causes $\mathrm{CaCO}_{3}$ to dissolve. Magnesium varied from 4 ppm (S3) to 186 (S2) ppm. Bangladesh standard of magnesium is $30-35 \mathrm{ppm}$, where $22 \%$ of the sample contains magnesium above the standard. This may be due to high solubility of $\mathrm{Mg}$; the metals tend to remain in solution and are less readily precipitate than calcium.

The concentration of chloride in the area varied from 70 to $1250 \mathrm{ppm}$ in pond water where Bangladesh standard is $150-600 \mathrm{ppm}$. Twenty nine per cent samples of pond water exceeded the potability standard and near about $16.13 \%$ samples of pond water exceeded the tolerable concentration of chloride in the coastal region $(1000 \mathrm{mg} / \mathrm{l})$. The higher value of chloride in pond water indicates the admixture of mineralized water or pollution (Narayana and Suresh 1989).

Commonly the natural water contains bicarbonate less than $500 \mathrm{mg} / \mathrm{l}$ (Todd 1980). Carbonate and bicarbonate represent alkalinity of water. The concentration of bicarbonate at different location ranges from 25 to $600 \mathrm{ppm}$ in pond water. It is evident that bicarbonate has a correlation with $\mathrm{K}^{+}(0.67)$ and $\mathrm{pH}(0.49)$. Bicarbonate is the primary anion in the water, which is mainly derived from carbon dioxide released by the organic decomposition in the soil (Todd 1979). Most of the bicarbonate must have been derived from the soil $\mathrm{CO}_{2}$ (Sivasankaran and Ramesh 2005). 


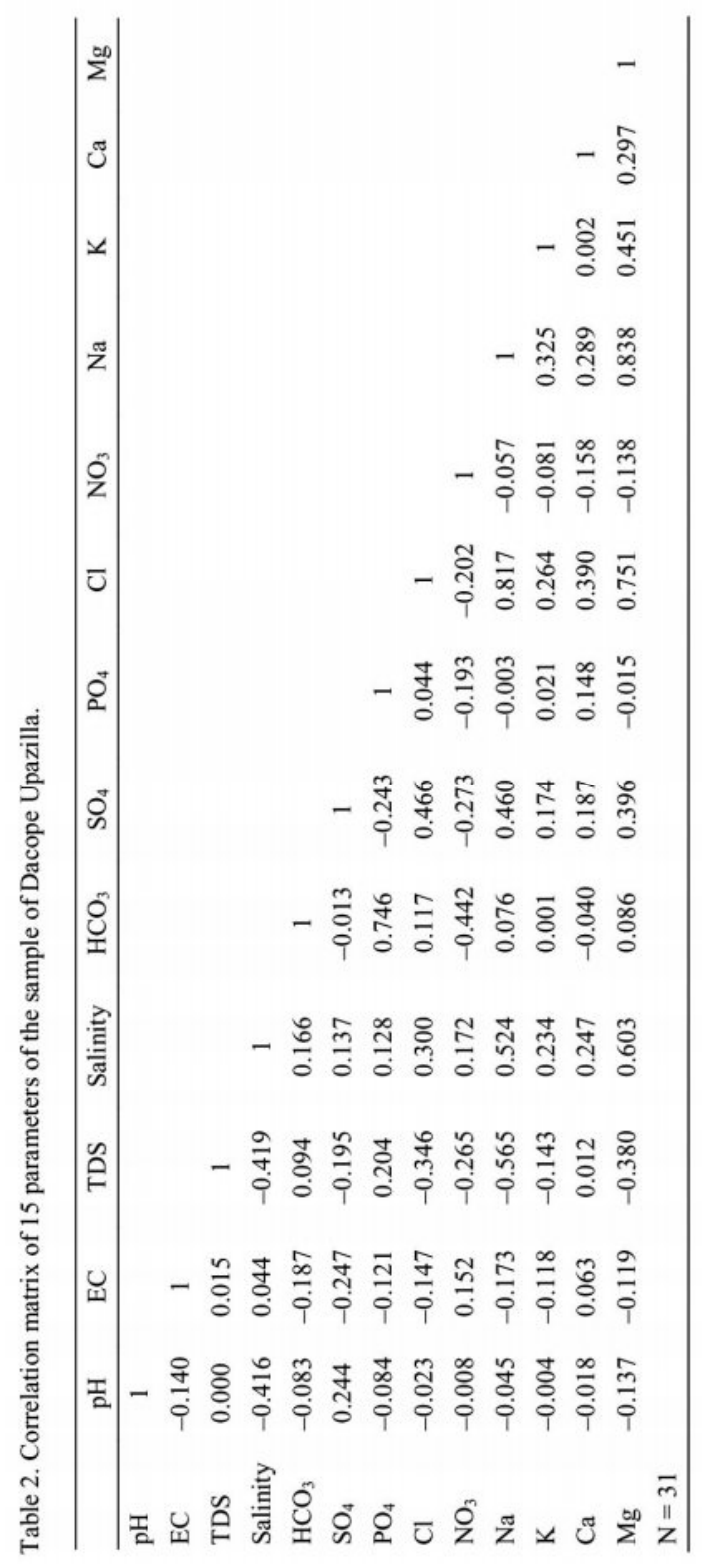


The concentration of phosphate ranged from 1.84 to $6 \mathrm{ppm}$ in pond water in the area, where Bangladesh standard is $6 \mathrm{ppm}$. It is found that most of the samples showed very low concentration of phosphate compared to the standard.

Sulphate is one of the major anions occurring in natural waters. Considerable sulphate is added to the hydrologic cycle from precipitation (Sivasankaran and Ramesh 2005). This comes from dried sea spray as cyclic salt, continental dust, oxidation of $\mathrm{H}_{2} \mathrm{~S}$ that enters the atmosphere from coastal marshes and air pollution (Matthess 1982). In the study area considerable sulphates may have been added due to the decomposition of organic matter in soil. Natural water contains generally less than $300 \mathrm{ppm}$ sulphate (Todd 1980). The concentration of sulfates varied from 16 to $342 \mathrm{ppm}$ in pond water. Sulfate has also correlation with the $\mathrm{K}^{+}(0.174), \mathrm{Na}^{+}(0.460), \mathrm{Ca}^{2+}(0.187), \mathrm{Mg}^{2+}(0.396)$, and $\mathrm{Cl}^{-}(0.466)$. Considerable sulfate is added to the hydrologic cycle from precipitation (Sivasankaran and Ramesh 2005). In the study area sulfate concentration is within the standard value of Bangladesh $(400 \mathrm{ppm} / \mathrm{l})$. The concentrations of nitrate-nitrogen ranged from 1.65 to 6.50 ppm in pond water in the study area.

Correlation matrices: According to Hounslow (1995) the relationship between two variables is called correlation, and it measures the degree to which two variables vary together (or vary inversely). It is measured by an index called correlation coefficient (r), where the value of $r$ vary from -1 to +1 . Correlation between ions suggests the likely source of surface water.

From the above correlation matrix it is found that, there is a strong correlation between magnesium and chloride, sodium and chloride, where the correlation value is 0.751 and 0.817 , respectively. In this study, chloride, sodium and magnesium have significant correlation with salinity, the value is $0.300,0.524$ and 0.603 , respectively. It is also found that the ions have no significant effect on EC and TDS. Negative correlation is found between those ions and parameters.

The result suggests that $\mathrm{Na}$ has strong positive correlation with $\mathrm{Cl}$, that $\mathrm{Na}$ and $\mathrm{Cl}$ is coorigin in nature. $\mathrm{Mg}$ shows moderate correlation with $\mathrm{SO}_{4}$, so there is possibility of seawater intrusion. $\mathrm{K}$ shows poor correlation with $\mathrm{HCO}_{3}$, so carbonate weathering is rare.

Source rock deduction according to parameter ratio: The ions commonly determined in a water station includes $\mathrm{Na}^{+}, \mathrm{K}^{+}, \mathrm{Ca}^{2+}, \mathrm{Mg}^{2+}, \mathrm{Cl}^{-}, \mathrm{SO}_{4}{ }^{2-}$ and $\mathrm{HCO}_{3}{ }^{-}$(Table 3). Other parameter includes TDS and hardness. It is essential for water quality analysis to determine the source of major elements that are found in water and the ways by which they may be removed from solution. The initial composition of groundwater originates from rainfall which may be considered to be diluted seawater. 
During its return path of ocean, the water composition is altered by rock weathering, evaporation (Gibbs 1970) and aeration. During rock weathering $\mathrm{Ca}^{2+}, \mathrm{Mg}^{2+}, \mathrm{SO}_{4}{ }^{2-}, \mathrm{HCO}_{3}{ }^{-}$ are added to the water. The amount of each is dependent on the rock mineralogy.

Table 3. Source rock deduction summary of the water samples (Hounslow 1995).

\begin{tabular}{|c|c|c|c|}
\hline Parameter & $\begin{array}{l}\text { Attention value } \\
(\mathrm{mmol} / \mathrm{l})\end{array}$ & $\begin{array}{l}\text { Analysis } \\
\text { value } \\
(\mathrm{mmol} / \mathrm{l})\end{array}$ & Conclusion \\
\hline$\frac{N a^{+}+K^{+}-C l^{-}}{N a^{+}+K^{+}-C l^{-}+C a^{2+}}$ & $\begin{array}{l}>0.2 \text { and }<0.8 \\
<0.2 \text { and }>0.8\end{array}$ & 0.557 & $\begin{array}{l}\text { Plagioclase weathering } \\
\text { possible } \\
\text { Plagioclase weathering } \\
\text { unlikely }\end{array}$ \\
\hline$\frac{N a^{+}}{N a^{+}+C l^{-}}$ & $\begin{array}{l}>0.5 \\
=0 \\
<0.5 \text { TDS }>500 \\
<0.5 \text { TDS }<500 \\
<0.5 \text { TDS }<50\end{array}$ & 0.475 & $\begin{array}{l}\text { Sodium sources other than } \\
\text { halite-albite ion exchange } \\
\text { Halite solution } \\
\text { Reverse softening, sea } \\
\text { water } \\
\text { Analysis error } \\
\text { Rainwater }\end{array}$ \\
\hline$\frac{\mathrm{Ca}^{2+}}{\mathrm{Ca}^{2+}+\mathrm{SO}_{4}^{2-}}$ & $\begin{array}{l}=0.5 \\
<0.5 \mathrm{pH}<5.5 \\
<0.5 \text { neutral } \\
>0.5\end{array}$ & 0.397 & $\begin{array}{l}\text { Gypsum dissolution } \\
\text { Pyrite oxidation } \\
\text { Calcium removal- ion } \\
\text { exchange or calcite } \\
\text { precipitation } \\
\text { Calcium sources other } \\
\text { than gypsum-carbonates } \\
\text { or silicates. }\end{array}$ \\
\hline$\frac{\mathrm{Cl}^{-}}{\text {sumanions }}$ & $\begin{array}{l}>0.8 \text { TDS }>500 \\
>0.8 \text { TDS }<100 \\
<0.8\end{array}$ & 0.676 & $\begin{array}{l}\text { Sea water or brine or } \\
\text { evaporates } \\
\text { Rainwater } \\
\text { Rock weathering }\end{array}$ \\
\hline$\frac{\mathrm{HCO}_{3}^{-}}{\text {sumanions }}$ & $\begin{array}{l}>0.8 \\
<0.8 \text { sulphate high } \\
<0.8 \text { sulphate low }\end{array}$ & 0.103 & $\begin{array}{l}\text { Silicate or carbonate } \\
\text { weathering } \\
\text { Gypsum dissolution } \\
\text { Seawater or brine. }\end{array}$ \\
\hline TDS & $\begin{array}{l}>500 \\
<500\end{array}$ & $\begin{array}{l}>500 \\
<500\end{array}$ & $\begin{array}{l}\text { Carbonate weathering or } \\
\text { brine or seawater } \\
\text { Silicate weathering }\end{array}$ \\
\hline
\end{tabular}

The ratio $\frac{\mathrm{Na}^{+}+\mathrm{K}^{+}-\mathrm{Cl}}{\mathrm{Na}^{+}+\mathrm{K}^{+}-\mathrm{Cl}+\mathrm{Ca^{+ }}}$ shows if the result is $>0.2$ and $<0.8$, there plagioclase weathering is possible. The samples show the possibility of plagioclase weathering. 
The ratio $\frac{\mathrm{Ca}^{2+}}{\mathrm{Ca}^{2+}+\mathrm{SO}_{4}^{2-}}$ shows if the result is $<0.5$ then the source of calcium is removal of ion exchange or calcite precipitation.

All stations from the study area show the source of calcium is removal of ion exchange or calcite precipitation.

The ratio $\frac{\mathrm{Na}^{+}}{\mathrm{Na}^{+}+\mathrm{Cl}^{-}}$shows if the result is $<0.5$ then the sodium source is other than halite solution or reverse softening, sea water.

The stations from the study area show that the sodium source is other than halite solution or reverse softening, sea water.

From the ratio if $\frac{\mathrm{Cl}^{-}}{\text {Sumanions }}$ is $<0.8$ then the stations are from rock weathering. Here shows the stations are from rock weathering.

From the ratio $\frac{\mathrm{HCO}_{3}^{-}}{\text {Sumanions }}$ if the result is $<0.8$ and sulfate is low, then the source is seawater or brine but if the sulfate is high, the source is gypsum dissolution. Most of the stations from the study area are from seawater and a few from gypsum dissolution.

Sources of water according to piper (after Piper 1953): Piper diagram is a combination of anions and cations triangle that lies on a common baseline. Per cent meq/l are plotted on piper diagrams, approximate ratios may be calculated by measuring the placement of the sample on the diagram. Four basic conclusions can be derived from the Piper multiple analyses plotted on Piper diagram (Hounslow 1995). These are: (1) Water type, (2) precipitation or solution, (3) mixing and (4) ion exchange.

Water that plots at the top of the diamond is high in (pond water) both $\mathrm{Ca}^{2+}+\mathrm{Mg}^{2+} ; \mathrm{Cl}^{-}$ and $\mathrm{Na}^{+}+\mathrm{K}^{+}$, which results in an area of salt water mixing as shown in figure 1 . The pond sand filtered water also has the same nature. Plotting the collected 31 samples from different sources of Dacope Upazilla and from the nature of Piper diagram, it is clear that the area is in abundance with $\mathrm{Na}, \mathrm{Cl}$ and $\mathrm{Mg}$. The presence of $\mathrm{Na}$ and $\mathrm{Cl}$ suggest the salinity of the area and the presence and abundancy of $\mathrm{Mg}$ suggest the sea water intrusion from surrounding shrimp culture ghers or other locations and its marine source.

Ionic hierarchy: A higher hierarchy of ions can be established based on the relative importance of marine sea salt sources and continental sources.

$$
\begin{aligned}
& \mathrm{Cl}^{-}=\mathrm{Na}^{+}>\mathrm{Mg}^{++}>\mathrm{K}^{+}>\mathrm{Ca}^{++}>\mathrm{SO}_{4}{ }^{--}>\mathrm{NO}_{3}{ }^{-}=\mathrm{NH}_{4}{ }^{+} \\
& \text {mostly marine mostly continental }
\end{aligned}
$$




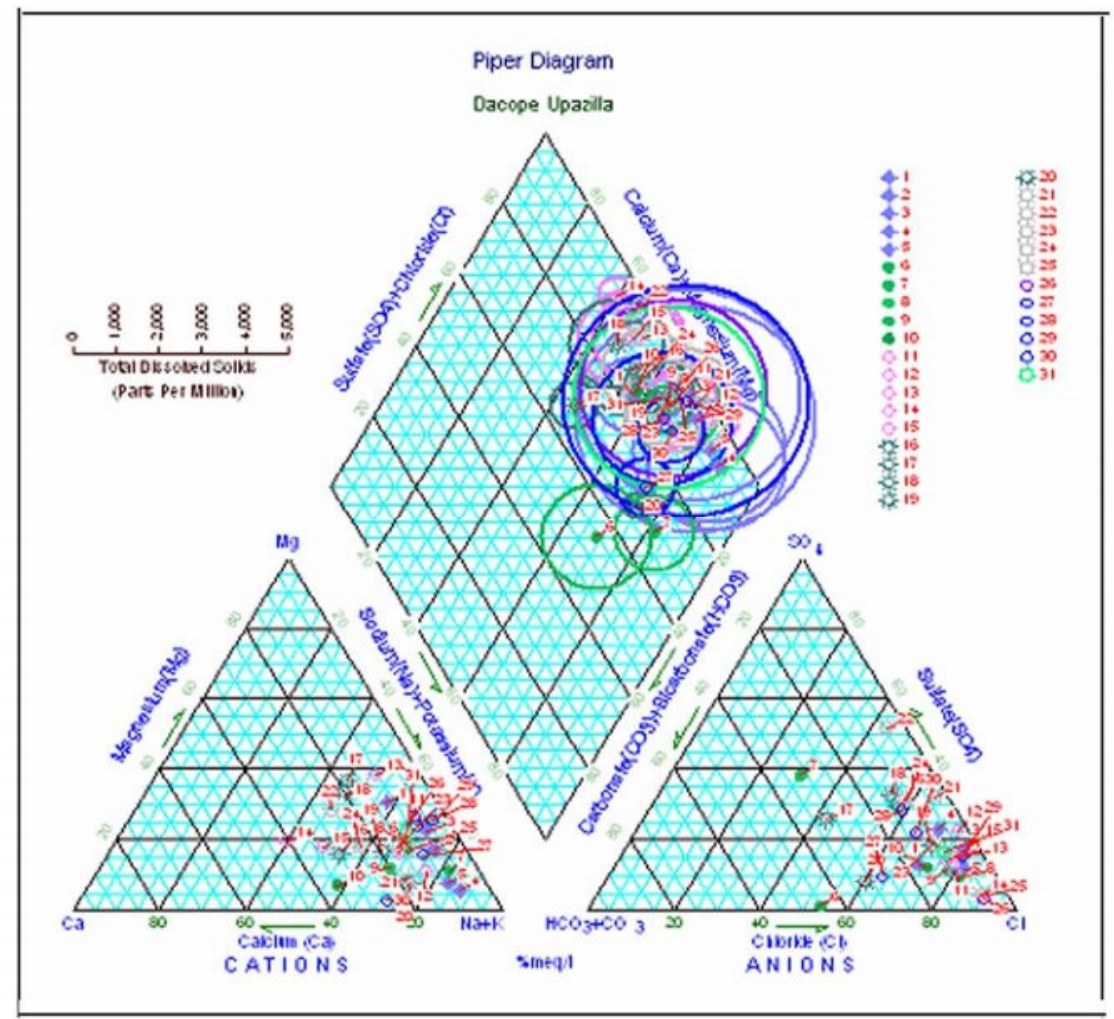

Fig. 1. Piper diagram of the study area.

Surface water containing significant amount of chloride also tend to have high amount of $\mathrm{Na}$ ions indicating the possibility of contacts with water of marine origin. The major cations of the average surface water in Dacope upazilla are in the order of $\mathrm{Na}^{+}>\mathrm{Mg}^{++}>$ $\mathrm{Ca}^{++}>\mathrm{K}^{+}$and major anions are in the order of $\mathrm{Cl}^{-}>\mathrm{SO}_{4}{ }^{2-}>\mathrm{HCO}_{3}{ }^{-}$(Table 4). The samples of pond water shows highest chloride concentration and higher concentration of bicarbonate sulfate than bicarbonate. The analytical data reveal that sodium and chloride are the dominant ions in the study area.

In general, sodium is the dominant cation in most surface water. It is also evident that if $\mathrm{Na}>>\mathrm{K}$ then $\mathrm{K}$ is more readily removed from solution by plants and clay mineral than sodium. Both elements are equally common in most rocks originating as constituents from the weathering of feldspars (albite and $\mathrm{K}$ feldspar) and micas. In addition sodium commonly occurs from ion exchange (Hounslow 1995). Because of its lower 
geochemical mobility in freshwater, potassium is seldom found in greater or almost equal concentration of sodium $\left(\mathrm{Na}^{+}\right)$.

Table 4. Summary output of ANOVA analysis of the samples results.

\begin{tabular}{lccc}
\hline Groups & Count & Sum $(\mathrm{meq} / \mathrm{l})$ & Average $(\mathrm{meq} / \mathrm{l})$ \\
\hline $\mathrm{HCO}_{3}{ }^{-}$ & 31 & 66.2613 & 2.137461 \\
$\mathrm{SO}_{4}{ }^{2-}$ & 31 & 110.7752 & 3.573394 \\
$\mathrm{PO}_{4}{ }^{3-}$ & 31 & 2.373 & 0.076548 \\
$\mathrm{Cl}^{-}$ & 31 & 463.48 & 14.95097 \\
$\mathrm{NO}_{3}{ }^{-}$ & 31 & 1.669 & 0.053839 \\
$\mathrm{Na}^{+}$ & 31 & 394.58 & 12.72839 \\
$\mathrm{~K}^{+}$ & 31 & 14.607 & 0.471194 \\
$\mathrm{Ca}^{2+}$ & 31 & 72.753 & 2.346871 \\
$\mathrm{Mg}^{2+}$ & 31 & 118.599 & 3.825774 \\
\hline
\end{tabular}

Table 5. Drinking water standards (DoE 1997).

\begin{tabular}{lllll}
\hline $\begin{array}{l}\text { Water quality } \\
\text { parameter }\end{array}$ & Unit & $\begin{array}{l}\text { Bangladesh } \\
\text { standard }\end{array}$ & $\begin{array}{l}\text { WHO standard } \\
(1993)\end{array}$ & $\begin{array}{l}\text { Study result from } \\
\text { Dacope Upazilla }\end{array}$ \\
\hline $\begin{array}{l}\text { Temperature } \\
\text { pH }\end{array}$ & ${ }^{\circ} \mathrm{C}$ & $20-30$ & - & $27.6-35.3$ \\
EC & - & $6.5-8.5$ & $7-8.5$ & $6.40-7.75$ \\
TDS & $\mu \mathrm{s} / \mathrm{cm}$ & - & - & $1.50-14.25$ \\
Sodium $\left(\mathrm{Na}^{+}\right)$ & $\mathrm{ppm}$ & 1000 & 1000 & $204-5510$ \\
Potassium $\left(\mathrm{K}^{+}\right)$ & $\mathrm{ppm}$ & 200 & 200 & $50-934$ \\
Calcium $\left(\mathrm{Ca}^{2+}\right)$ & $\mathrm{ppm}$ & 12 & - & $3.5-70$ \\
Magnesium $\left(\mathrm{Mg}^{2+}\right)$ & $\mathrm{ppm}$ & 75 & $75-200^{*}$ & $22-120$ \\
Chloride $\left(\mathrm{Cl}^{-}\right)$ & $\mathrm{ppm}$ & $30-35$ & $50-150^{*}$ & $4-186$ \\
Bicarbonate $\left(\mathrm{HCO}_{3}{ }^{-}\right)$ & $\mathrm{ppm}$ & $150-600^{*}$ & $200-600$ & $70-1250$ \\
Phosphate $\left(\mathrm{PO}_{4}{ }^{3-}\right)$ & $\mathrm{ppm}$ & 6 & - & $25-600$ \\
Sulfate $\left(\mathrm{SO}_{4}{ }^{2-}\right)$ & $\mathrm{ppm}$ & 400 & - & $1.84-6$ \\
Nitrate $\left(\mathrm{NO}_{3}{ }^{-}\right)$ & $\mathrm{ppm}$ & 10 & 250 & $16-342$ \\
\hline
\end{tabular}

* For coastal areas of Bangladesh, in case of non-availability of alternative sources value is 1000.

Potability status of pond water: Drinking water quality refers water supplies which is free from any potential health hazard to the consumers. The different impurities in water which cause undesirable effects may be classified into physical, chemical, bacteriological and radiological parameters. 
The standards prescribed for potable water supplies by different authorities usually give two types of norms e.g. permissible and tolerable range. Bangladesh has also set a national standard for different physical, chemical and biological parameters level for drinking water. WHO $(1992,1993)$ has set international standard for drinking.

To assess the suitability of potable surface water for drinking, WHO and Bangladesh have standards for different parameters (Table 5).

According to the drinking water standards of WHO and Bangladesh, it is summarized that the results from the laboratory analysis sometimes have been exceeded and sometimes remained below the standard. In case of some parameters, the result is quite satisfactory for the standards. But it can be easily said that the water used for drinking purpose, is no more suitable for the local inhabitants.

The protected ponds in Dacope Upazilla, annually replenished by rainwater are the main source of potable water in the area. However, various uses and unhygienic practices pollute these ponds. In some areas, due to high salinity problem, around $36 \%$ of households have been found to harvest rain water in the rainy season for drinking purposes. But the quality of this water is deteriorated due to improper management of preservation. Collection, storage and usage pattern of rainwater are not in an organized manner and development through adoption of appropriate technologies.

\section{References}

APHA 1992. Standard Method for the Examination of water and waste water $\left(14^{\text {th }}\right.$ ed.). American Public Health Association, New York.

BBS, 1996. "Population Census, Community Series, Khulna District", Statistics Division, Ministry of Planning, Dhaka, Bangladesh.

Gibbs, R.J. 1970. Mechanisms Controlling World Water Chemistry, Science 170: 1088-1090.

Hounslow, A.W. 1995. Water Quality Data: Analysis and Interpretation, Lewis Publ, Oklahoma, $397 \mathrm{p}$.

Matthess, G. 1982.The properties of groundwater, John Wiley and Sons, New York. 350 p.

Narayana, A. and G. Suresh.1989. Chemical quality of groundwater of Mangalore City, Karnataka. J. Env. Health. 31(3): 228-236.

Piper, A.M. 1953. A graphic procedure in the geochemical interpretation of water analysis., USGS Ground Water Note, No. 12 : 63.

Rashid H. 1991. Geography of Bangladesh ( $2^{\text {nd }}$ Edition). University Press Limited, Dhaka, Bangladesh. 579 pp.

Saha, S.K., S. Naznin and F. Ahmed. 2006. A Household based safe water intervention programme for a slum area in Bangladesh. Asian Journal of Water, Environment and Pollution 3(1): 2125. 
Sivasankaran. M. A. and R. Ramesh. 2005. Geochemical characterization of groundwater in the Pondicherry region India. In: Ramesh, R., S. Ramachandran. (Eds). Freshwater Management. Capital Publishing Company. New Delhi: 92-107 p.

Todd, D.K. 1980. Groundwater Hydrology, University of California, Berkeley, John Wiley and Sons, 2nd Edition. 312 p.

Umitsu M. 1993. Late Quaternary environment and landforms in the Ganges delta. Sed. Geol. 83: $177-186$.

World Health Organization, 1992. The International Drinking Water Supply and Sanitation Decade. Geneva, Switzerland.

World Health Organization, 1993. Guidelines for Drinking Water Quality, Second Edition, Volume 1, Recommendation, Geneva.

(Revised copy received on 20.10.2018) 